\title{
What hope is there - for Klaus?
}

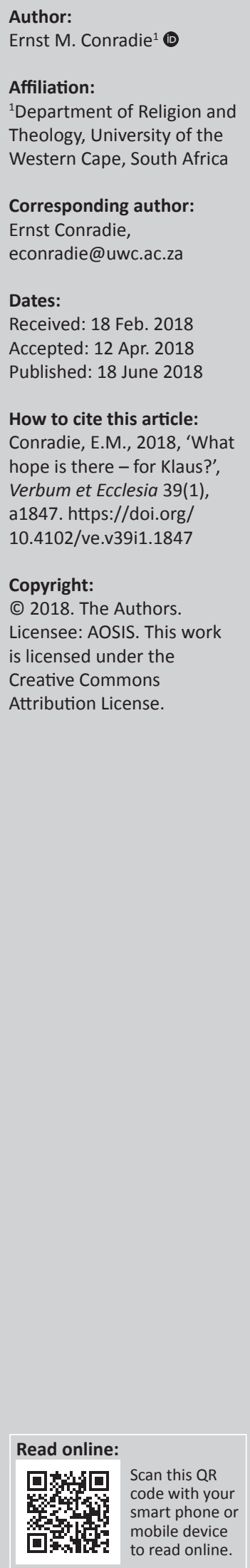

This contribution engages with Klaus Nürnberger's eschatology as expressed in his Invitation to Systematic Theology. It suggests that his notion of Christian hope has to be understood in terms of the triad of core concepts that he offers, namely creative power, benevolent intentionality and a vision of comprehensive optimal well-being. These are dialectically related as thesis, antithesis and synthesis. Moreover, this dialectic comes to expression in his understanding of faith in the Triune God, namely as belief in God against God, God as Saviour against God as Creator. Two questions regarding the vision of comprehensive optimal wellbeing are raised in conversation with Nürnberger: Firstly, is the content of Christian hope focused on optimal well-being itself, that God's project will prevail, that the vision itself will prevail or that God will prevail. Can these be treated as rough synonyms? Secondly, what are the implications of the emphasis on God's Word for Nürnberger's eschatology? Does his emphasis on conceptual clarification not allow a form of idealism that undermines his own emphasis on the historical? If so, is there sufficient room for the consummation of all things as part of the narrative of God's work?

Intra- and interdisciplinary implications: This contribution is of an intradisciplinary nature and is located within the field of Christian systematic theology. It is a review article that engages critically with the position on eschatology adopted by Professor Klaus Nürnberger in his two-volume work Faith in Christ Today (2016).

Friends, Romans, countrymen, give me your attention. I have come here to bury Caesar, not to praise him. The evil that men do is remembered after their deaths, but the good is often buried with them. It might as well be the same with Caesar. The noble Brutus told you that Caesar was ambitious. If that's true, it's a serious fault, and Caesar has paid seriously for it. With the permission of Brutus and the others - for Brutus is an honourable man; they are all honourable men - I have come here to speak at Caesar's funeral. He was my friend, he was faithful and just to me. But Brutus says he was ambitious, and Brutus is an honourable man. He brought many captives home to Rome whose ransoms brought wealth to the city. (Anthony's speech from William Shakespeare, Julius Caesar, Act 3, Scene 2) ${ }^{1}$

\section{An irreverent form of praise}

We have come together to praise Klaus before we bury him - and that would hopefully not be soon. Like Brutus, Klaus is indeed an honourable man, but would not want that to be mentioned too often. Like Caesar, Klaus is an ambitious man, although you will not detect it from his body language. It is evident from his immense courage to produce a systematic theology, already in his early career (nogal in Afrikaans) and now as the capstone of his oeuvre. Is that a fault and will he seriously pay for that? Probably, because any systematic theology inevitably fails in the end - for what is privileged and for what is omitted and for the inadequacies of any set of concepts to capture the Christian faith. The task of theology, he says, is to reflect on such faith, to establish what Christians ought to believe and to reflect on what they actually believe but maybe should not (Nürnberger 2016a:5). ${ }^{2}$ To produce such a systematics is therefore a humbling experience - for the author (who becomes so very exposed) as well as for readers (like me) who cannot but admire the immensity of this project and its incredible wealth of detailed analysis on such a wide variety of topics. Nürnberger's thorough engagement with the biblical texts (see also Nürnberger 2002) and his pioneering work on hermeneutics should be widely appreciated.

1.See http://nfs.sparknotes.com/juliuscaesar/page 132.html (accessed 18 January 2018). I opted for the modern 'translation' to honour Klaus Nürnberger's wish for clarity by transferring the message from its historical forms to modern expressions (see Nürnberger 2016a:11) - although I admit to be 'lost in translation' because the classic 'lend me your ears' is much more preferable at least for me. We do need to 'clean up our language' (2016b:47), but that cannot mean that metaphors are to be replaced with at least for me. We do need to 'clean up our language' (2016b:47), but that cannot mean that metaphors are to be replaced with concepts. This would be reductionist and would translate the Christian faith into something that it is not. If at times (when the emperor really wears no clothes), we need to demythologise obscure theological constructions, more often we need to clothe our existence with alluring myths - or else stand naked before God and one another. Whereas Nürnberger explains the task of theology as to retrieve the core of the biblical message from its ancient packaging and reconceptualise it in terms of our current worldview' (Nürnberger 2016b:466), I would maintain that we cannot invent root metaphors or symbols and that they have ontological priority over the concepts that we do employ to explain them.

2.Unless otherwise indicated, references in brackets dated 2016a or 2016b refer to the two volumes of Klaus Nürnberger's Invitation to Systematic Theology. 
For any systematic theologian (what a misnomer), there is only one thing that is worse than offering (an apt term!) a 'systematics' and that is failing to do so - or pretending that one does not hold one tacitly, or acknowledging how inconsistent one's views are. ${ }^{3}$

Unlike Caesar, Klaus would never bring captives home, although he has regularly captivated audiences. Every fibre in his being would resist demanding any ransom, yet he has brought great wealth at least to the South African academy. Following Jesus in his many books on economic justice, ${ }^{4}$ Klaus would be quite willing, where need be, to pay a ransom so that others may live.

Once we do bury Klaus (and he may outlive some of his readers), his body will be eaten by worms and maggots (cremation provides no exception), making way for the lives of others - at least that is what he says himself (2016b:502). He will become food for others to live. What hope, then, is there for Klaus? Is there life beyond his death?

Surely, in his case, the evil that he may have done will be forgotten, while many good things will be remembered. Klaus' legacy will certainly live on for many years to come, in the memories of his colleagues and students and then in his books that add value to our libraries. His many contributions will be prescribed and read as textbooks, studied, examined, cited (contrary to his fears in this regard ${ }^{5}$ ) and critically assessed by coming generations of students. ${ }^{6}$ To be sure, history will be the judge, but history too may go wrong. Eventually, a few centuries from now, it may become hard to find copies of his books, even though what becomes of Google. Klaus' legacy will dissipate and disperse into a collective of the South African theologies around the turn of the 21st century. That would be a real shame because his oeuvre typically resists what is taken for granted by others. Klaus admits to be a loner. Inevitably, even if this takes thousands of years, his distinct individuality will wither away and be lost. There is hope though, in the form of objective immortality. Not even an almighty God can undo what has once happened in history. The facts of Klaus'

3.To make an admission, i have made a brief sketch for what i hope to call an 'earthed dogmatics'. The scale of such a project is intimidating to say the least, hence my dogmatics'. indebtedness to Klaus for making this project avallable to us. For the recognition Graham Ward who is himself engaged in a multivolume systematic theology project (see Ward 2016).

4.See, especially, Nürnberger $(1998,1999)$ and Making Ends Meet (1995), for me one of Klaus' best books for the laity.

5.The pre-final version of Klaus Nürnberger's manuscript (received for peer review purposes) included this in the final section:

'If I have regrets, it is that my work never received the attention I would have hoped for. Some of what I consider to be my best books were never discovered.
The impact I made on the theological scene, nationally and internationally, was The impact

It may have been wise to revise this, precisely because such fears may well be mistaken!

6.I suspect that such students will bemoan the paucity of footnotes (see 2016a:xx) and references to other literature in order to see how Nürnberger aligns or distance himself from other views. They will read this work alongside others and will need to be helped to see where some of the ideas come from and how this may be different from other positions. The appendices are therefore to be welcomed, but even there from other positions. The appendices are existence, his life and work, cannot be erased. ${ }^{7}$ At the very least, it will be retained and redeemed in God's memory (2016b:502). That is not by itself good news, though, as all our sins, all the atrocities of history, have the same immortality. Is this our last, best hope then? What hope is there for Klaus?

With this rather irreverent form of praise, let me offer a few comments on Klaus Nürnberger's eschatology. The question is how Klaus understands the content and significance of Christian hope - and not so much whether there is hope for his eschatology in terms of scholarly assessment. Eschatology is after all not 'his'; in his terminology, it expresses a trust in God's vision of comprehensive, optimal well-being.

\section{A creative tension within Nürnberger's triad}

It would be inappropriate to focus only on the final two chapters of Klaus Nürnberger's Invitation to Systematic Theology to capture his understanding of the content and significance of Christian hope. This is not merely because of the comprehensive and consistent character of his theological 'vision' (2016a:xix), where every part should be understood in terms of his methodological preference for 'experiential realism' (2016a:1722, 2016b:45-71). Hope amidst anxiety, suffering, injustices and evil infuses the whole text (see, e.g., 2016a:104-112). Like Jürgen Moltmann's, this is a theology of hope, albeit the approach and also the content are quite different.

The most significant reason why all the main parts are relevant has to do with the 'creative tension' (to hint at David Bosch, Klaus' former colleague at Unisa) that Nürnberger maintains between the two core themes of creation and salvation (or redemption). ${ }^{8}$ He consistently seeks to hold together God's creative power and benevolent intentionality. To his credit, he resists conflating creation and salvation, that is, to speak of creation as salvific or salvation as creative. Such an emphasis is as true as it is facile and circumvents the hard problems that have to be addressed. ${ }^{9}$

7.See his formulation (Nürnberger 2016b):

We do not leave the world when we die but, like everything that ever existed or happened, our life drops into past history from which it can never be retrieved, but from which it also cannot ever be erased. What matters is not its infinite continuation, but its quality while in progress. (p. 502)

8.I could not detect any clear distinction in Nürnberger's use of the terms salvation and redemption. Both are of course metaphors that have become extended to speak of God's work and often operate as rough synonyms. For some, redemption is best used eschatologically, but this is not the case with Nürnberger. For him, redemption is tied with God's benevolent intentionality. He defines it in this way: 'In this book I use the term "redemption" in the sense of the transformation of what ought not to have become into what ought to become' (2016b:377). He occasionally ought not to have become into what ought to become' (2016b:377). He
speaks of salvation in relation to all three terms in the triad (2016a):

... salvation means nothing else but to be in fellowship with God, sharing God's creative power, redeeming love and comprehensive vision for 'his' world. It is sin that alienates us from God; so it is sin from which we must be redeemed. (p. 279) It seems that, for Nürnberger, redemption has comprehensive scope, while salvation addresses the 'inner circle' of spiritual needs (2016b:374), especially for acceptance and therefore for forgiveness and healthy relationships. This is odd because 'saving' in everyday usage refers to a rescue operation from drowning, disasters and attack (see also 2016b:424).

9.On the need to maintain a creative tension between God's work of creation and salvation, see the three volumes that I edited in this regard (Conradie 2011a, 2011b, 2012) and two subsequent monographs (Conradie 2013, 2015). I have attempted to explain why it is important but also so difficult to do justice to both creation and salvation. This tension is already evident in common categories such as 'animal welfare', 'black consciousness', 'environmental sustainability', 'human dignity' and 'women's emancipation'. I was therefore pleased to see that Nürnberger maintains 'women's emancipation'. I was therefore pleased to see that Nürnberger maintains
the tension in this regard, almost as a binary opposition - and does not resolve that tension eschatologically either. 
Eschatology (the consummation of God's work) is the appropriate locus (site of struggle?) where the creative tension between creation and salvation plays itself out. To return to Caesar as metaphor, this is where the Rubicon is crossed, where the die is cast (alea iacta est). For Nürnberger, this means that God's creative power and benevolent intentionality is held together by God's vision of comprehensive well-being for the world as manifest in Jesus Christ (2016a:xi).

All these three aspects of God's work go against the realities that people experience in their everyday lives - or on the broader canvas of history. This is Nürnberger's 'experiential realism' - which is not to be confused with what we really experience (despite 2016a:18). ${ }^{10}$ What we experience is deeply ambiguous (2016a:34), a mix of joys and frustrations, life and death, corruption and fruition, power and powerlessness, limitations and prospects. What 'realism' entails is a refusal to engage in abstract metaphysical speculation in order to confront the world as we experience it around us. This means to take the sciences that describe how the world works seriously. ${ }^{11}$ For faith to be 'real', it has to be expressed and experienced within such a context, or not at all. In the midst of such experiences, it is deeply counter-intuitive to hold onto the proclaimed benevolent intentionality. ${ }^{12}$ For Nürnberger (and here he follows his Lutheran intuitions), this is what a life of faith entails: a struggle with God against God for God's work is sub contrario; it becomes manifest best in its opposite - as the symbol of the cross suggests. The cross is the 'prototype of God's suffering, transforming acceptance of the unacceptable' (2016a:39, 43). The Christian faith, he states in capturing his 'message in a nutshell' (2016a):

... responds to the 'Word of God', that is, the message of God's creative power, God's benevolent intentionality and God's comprehensive vision for the world as manifest in Christ. Believers entrust themselves to this message, live in the context of a community of believers and seek to be involved in God's creative and redemptive project. (p. xi)

10.This call for realism, really (excuse the pun!), requires further unpacking with reference to other literature. I am not convinced that the name 'says it all' (contra 2016a:28). To say that what is 'real' is anything that can be shown to exist and have consequences in the world (2016b:50) does not help much because that applies to lies, gossip, ideology, fallacies and climate change denial too. As I read it, Nürnberger aligns himself with Karl Popper's critical realism, picked up also in science and theology discourse, in order to ensure that theological reflection maintain 'traction' (Philip Clayton) with the natural sciences (Nürnberger's first love). However the emphasis on experience is not to be reduced to empiricism. The hands may hold scientific tools (especially the the ry of emergence that The hands may hold scientific tools (especially the theory of emergence that allows for a scientific acknowledgement of the role of spirituality as part of mmanent reality). However, the voice remains that of schleiermacher and Bultmann, albeit that the latter's existentialism is extended in Nurnberger's oeuvre to make room for a broader understanding of well-being that requires economic analysis

11.See also Nürnberger (2011) and my review essay on that book (Conradie 2012b).

12.Does such counter-intuition not apply to the whole triad of creative power benevolent intentionality and a vision of comprehensive well-being? It may not be obvious that the Transcendent Source of reality is benevolent, given human experience. This seems to take faith in God as Creator as a starting point. The inverse is also possible. Is it not counter-intuitive as well that God the Saviour is the One who Created? That would take faith in God as Saviour as starting point My sense is that Nürnberger takes the presence of creative power as self-evident and tasks science to describe such power. He insists that such power 'can be observed, task scien explored, and explained by any human being', albeit not everyone will recognise transcendent Source behind such power (2016a:34). Can faith in God as Creator then be derived from the creach power (2016a:34). Can faith in God as Creator in God as Creator not even less obvious than faith in God as Saviour (see Berkho 1985:151-157 - whose work, Nürnberger admits, comes close to his own position)? See also note 13 .
It should be noted that the tension between creative power and benevolent intentionality is immense. Such creative power, Nürnberger argues, is experienced in everyday life in the world around us and is best described with reference to the natural sciences (2016a:2), although both creative and destructive dimensions of power are evident and although it is not self-evident what the ultimate source of such power is. 'God', the name we give for the transcendent Source and Destiny of reality as a whole (2016a:2), is not necessarily for us; God may indeed be against us (2016a:29). By contrast, God's benevolent intentionality is not based on daily experience but is a conviction, maintained and proclaimed within a longstanding tradition that responds to the destructive power that is all too evident from daily experience - in the form of pain, suffering, anxiety, meaninglessness, injustices, oppression, ideological distortion, degeneration and death. This conviction is prompted by the Word of God (on which Nürnberger places considerable emphasis - 2016a:31-246). That God loves the whole world is indeed deeply counter-intuitive, given human experience of that world. ${ }^{13}$ Note that (the notion of) God's benevolent intentionality is therefore not experienced but communicated to us (2016a:34). Ideas can and do change the world after all.

There is an obvious dialectic at play here (see 2016b:7), if perhaps not a Hegelian or Marxist one. ${ }^{14}$ The thesis is the creative power that calls forth, given negative experiences of that power, a tension. Nürnberger insists that the reality that manifests God's creative power is highly ambiguous and that such ambiguity (2016b:306) is inescapable (2016b:310). ${ }^{15} \mathrm{He}$ then adds:

So instead of asking how faith can live with such a contradiction, we must ask how faith could possibly escape this contradiction! It is not a speculative postulate, but a profound reflection of the ambiguous character of the reality we actually experience. If there is no way we can get rid of ambiguity once and for all and in all aspects of life, we have to live with it. Living with it means to fight against it. We must opt for the beneficial against the

13.Elsewhere I have argued that the same applies to belief in God as Creator. To believe that this world, as we know and experience it, was created by the triune God, who is confessed to be loving and faithful, is even more counter-intuitive than belief in God as Saviour. That this world is to be understood as a loving God's creation is far from self-evident. That the triune God is the Creator is a matter of revelation that cannot be derived from science or natural revelation. See Conradie (2014, also 2015).

I concur with Nürnberger that we can only commence theological reflections with the world around us as we currently experience it (see 2016b:101), in all its grandeur and misery, with its flux and its consistencies. We cannot begin with constructions of what the world was like when God created it 'in the beginning' or what it ought to be. The Christian tradition, alongside other disciplines and traditions offers a set of interpretative categories that help us to make sense of the world around us. These interpretative categories evolve around a story of who God and what God is doing, has done and will do. All the three categories of creation, salvation and consummation form part of an interpretative grid structured in the form of narrative. Like Nürnberger, I would welcome the role of the sciences (alongside other disciplines) to help us make sense of the world around us. If theologians do not take cognisance of what such other disciplines are saying, it will not help anyone to make sense of this world around us. Unlike Nürnberger, I would link the role of sciences primarily to the world around us and not to the theme of 'creation'. Instead, I would argue that creation, salvation and consummation are theological categories that have to be held together as part of a narrative (Nürnberger 2016b:152f may suggest a 'system of meaning', but the word system is less dynamic than that of narrative). The story is told ever anew in the present to make sense of the past and to guide us towards the future. The question any child overhearing the story will ask is how the story will end.

14.See Nürnberger's critical position on Hegelian idealism and Marxist dialectical materialism (2016a:18).

15.The examples that Nürnberger offers are telling: the contradictory forces of gravity and entropy, the importance of death for life, or the simultaneous existence of th motivations of ruthless selfishness and loving concern in our brains (2016b:310). 
detrimental, for life against death, for good against evil (2 Chr 25:8). The existence of ambiguity in reality is no excuse for being ambiguous in our commitment. On the contrary, it calls for determined motivation and action to overcome evil as far as that is possible under any set of circumstances. (p. 310)

This underlying tension within created reality elicits the antithesis of benevolent intentionality. For Nürnberger, the dialectical tension between thesis and antithesis is best understood as one between what reality has become and what reality ought to be, through the eyes of faith, according to the trust in such benevolent intentionality (2016a:3). In fact, this tension is the heart of the Trinitarian mystery where God is posed against God. For Nürnberger, the Trinity is understood in experiential terms as (2016a):

... the tenacious clinging to the reassurance of God's benevolence in the face of all aspects of experienced reality that seem to question it. Faith doggedly insists that God's benevolence is the motivating power that underlies the cosmic process as a whole in spite of all its ambiguity and ambivalence. (p. 290)

\section{Indeed (2016b):}

Christians stubbornly uphold their faith in God 'against God' the God of redeeming grace against the God of merciless condemnation; the God of burning compassion against the God of a heartless reality; the God of personal involvement against the God of a meaningless mechanism. (p. 311)

Elsewhere he captures the deepest root of this dialectical tension:

The tension between the world we experience and the God we proclaim as its Source and Destiny is the deepest root of the dynamic found in the biblical faith. In this faith there is an irrepressible surge forward towards making good the promise of redemption in the face of depravity, meaninglessness, suffering and death. The most characteristic facet of the proclamation of the biblical faith is that God, the personal Source and Destiny of reality, is for us and with us and not against us - and that this benevolence of God is reliable, comprehensive and active, even if our experience seems to tell us otherwise. (pp. 407-408)

If one pushes the argument, faith in the Triune God is then a protest in the name of God the Saviour against God the Creator by insisting that this is indeed the same God. It is a struggle 'with God against God', with God's benevolent intentionality against the destructive power experienced in what is believed to be God's creation (2016b:312). This recognises that the first and second articles of the Christian creed are not held together easily; for Nürnberger they even contradict each other in experiential terms 'because they express the discrepancy between what reality has become and what reality ought to become' (2016b:301). In his categories: The transcendent Source and Destiny of this world, as we experience it, is unconditionally benevolent and such benevolence is universal (2016b:306). I concur with Nürnberger that shortcuts to an inner-Trinitarian mysticism are ill-advised without confronting issues around the economic Trinity. Indeed, only a deeply Trinitarian theology will do, but this is easier posed than accomplished (see Conradie 2013a).
The underlying dialectical tension is maintained throughout history as the expression of benevolent intentions that have not necessarily come to fruition (Klaus would not say that the road to hell is paved with such intentions). This tension is creative in the sense that it drives forth the history of the Jewish-Christian tradition. This is only possible given the dialectical synthesis, namely the vision of comprehensive optimal well-being. In fact, only through the synthesis of God's vision does it become possible to detect that it is this vision that underlies God's creative activity (2016b:203). As a vision, it can always be fulfilled only partially, but such a vision, Nürnberger argues, exerts a powerful influence in any new dispensation. This is the core of Nürnberger's eschatology.

\section{A vision of comprehensive optimal well-being}

An awareness of the dialectical tension between creative power and benevolent intentionality thus prompts the correlated tension between what reality has become and what it ought to be. For Nürnberger, what reality ought to become is another name for its destiny. That destiny, he suggests, 'refers to a vision of what reality ought to become' (2016b:16). Because cosmic reality is in a dynamic and unpredictable flux, such a destiny cannot be a predetermined goal, fixed forever through an eternal divine decree. Like the needle of a compass, that destiny indicates a direction rather than a preconceived ideal state. This direction (if not the compass itself) is God's vision of comprehensive optimal well-being (2016b:16, almost verbatim). Indeed, the vision forms part of immanent reality but 'God' is the name we may give to the transcendent destiny of reality as such.

There is something odd about this vision of comprehensive optimal well-being though. In a section entitled 'Is it our future that matters, or God's future?', Nürnberger (2016a:18-110) argues that Christian hope moved in the wrong direction when it became preoccupied with our individual future beyond death. He regards this as a form of spiritual selfishness that does not take creaturely limitations into account. Is the hope then that the vision will prevail, or for optimal wellbeing, taken creaturely limitations into account? Surely both, as God's project must include our times, our communities, us as individuals. For Nürnberger (2016a:109), this vision must be spelled out in concrete terms by addressing particular deficiencies in well-being. Visions do not materialise simply because they are there. They demand dedicated, coordinated and cooperative action (2016a:110, verbatim). Nevertheless, Christian hope is not based on inner-worldly possibilities and potentials but on the emergence and immersion of God's authoritative vision (2016a:111).

Yet, given the way in which the core concepts are stacked upon each other, one has to wonder whether the hope is for our optimal well-being, that God's project will come to fruition (not only in the end though), that the vision will prevail (even if optimal well-being is not maintained in different historical epochs) or that Godself will prevail as a 
constant reminder of the ultimate destiny of reality (which will happen by definition). ${ }^{16}$ These terms cannot be regarded as rough synonyms as the content and thus the social significance of such hope shifts in each case. Such a stacking up of terms plays itself out in different aspects of Nürnberger's project, including his discussion of the divine nature of Christ, ${ }^{17}$ the resurrection ${ }^{18}$ and pneumatology. ${ }^{19}$

How this oddity is unpacked is crucial in order to understand Nürnberger's eschatology and indeed his project as a whole. Recall for the moment the set of core concepts that Nürnberger employs for the dialectic synthesis: the sense amidst history of what reality ought to become, the destiny of reality as such, the vision of comprehensive optimal wellbeing (also described as God's project) and the suggestion that God is the name we may give for the transcendent destiny of reality. What exactly, then, is it that we may hope for? What is the content of such hope? What hope is there for Klaus?

\section{See the following formulation (2016b):}

We can indeed share the life of God within the constraints of time, space, energy and regularity that characterise our lives. On our own, we can only live in the present, and our present only lasts as long as we have a future that can change present, and our present only lasts as long as we have a future that can change
into past. When we run out of future, we will leave the scene, while the drama into past. When we run out of future, we will leave the scene, while the drama
of God's life continues without us. Then our lives will have been accomplished. (p. 504)

17.See Nürnberger's discussion of the human and divine 'natures' of Christ. He states in this regard (2016b):

The proclamation that God disclosed God's creative power and God's benevolent intentionality in and through the life, ministry and death of this particular human being does not imply, therefore, that this human being was ontologically different being does not imply, therefore, that this human being was ontologically different that that Jesus fully identified with God's redemptive intentionality. He proclaimed that enacted God's redeeming love. And God fully identified with Jesus' proclamation and enactment of God's redemptive intentionality. (p. 198)

This begs the question whether the Christ event was about a demonstration of God's benevolent intentionality or, in Nürnberger's terminology, of the Transcendence Source and Destiny of reality as such. Surely both, but if these are transcendence Source and Dest then wh transcendent is reduced to immant treated as synant reality and adds no value and can have no creative or redemptive influence in the world. or, put in classic theological categories, the person and the work of Christ cannot be separated from each other, but the person also cannot be reduced to the work of talking about in such a way that God-talk becomes merely a symbolic way of talking about human desires, projects and hopes.

18.Nürnberger's view of the meaning of Christ's resurrection is a case in point. He says (2016b):

The risen Christ is no longer a particular human being, constrained by his limited life time, his limited range of movement, his specific cultural and religious life time, his limited range of movement, his specific cultural and religious conditioning, his limited energy resources, but the prototype of a new way of
being human in fellowship with God. The 'risen Christ' stands for a new being human in fellowship with God. ... The 'risen Christ' stands for a new
humanity, which lives in fellowship with God and shares God's creative and comprehensive vision and 'his' redemptive action. (pp. 237-238)

Does the risen Christ then refer to a new humanity (that will disappear when humans become extinct), to the idea of a new humanity (that may prevail in a humans becom col's to the idea of a new humanity (that may prevail in Platonic realm), to God's messianic representative (who has objective immortality authority as the 'Son of God'? In other words: Does the resurrection refer to something that happened to Jesus or primarily to his disciples?

19.See Nürnberger (2016b:263-289). Here, too, there is a stacking up of concepts that are treated virtually as synonyms. Nürnberger states (2016b)

the Holy Spirit is the Spirit of Christ permeating, liberating, transforming and empowering the Body of Christ, the community of believers, for its mission in the world. The Spirit is the spiritual presence of the risen Christ among us. (p. 263)

And furthermore (2016b):

The Spirit is not a separate entity in heaven alongside God, or within God, but God's creative, redemptive and transformative presence in the spirit of a believing human community - and beyond that in the world as a whole. (p. 283)

I doubt whether Nürnberger would therefore appreciate Arnold van Ruler's call (see 1989) for a relatively independent pneumatology given a number of structura differences between Christology and Pneumatology. He claims a relatively unpreblematic continuity between the second and third articles of the Christian crictician creed (2016b:302), but the filioque controversy suggests immense ecumenica tensions here: Is the Spirit who transforms us indeed the Spirit of Christ (the classic Westen view) or does the Spirit also work in ? Pentecostals and several others may suggest)? In short, I detect a Pneumatological deficit in this 'invitation to systematic theology', already suggested by the title employed: 'Faith in Christ today'.
In the opening lines of the section on eschatology, Nürnberger raises the question with reference to God's transcendence (2016b):

Is the world we know, is the life we live, all there is? Is there nothing beyond the world depends on energy, regularity, space and time? If God transcends the reality we experience, does this not have a significance for our world and our lives in this world? Is there not a transcendent dimension of reality based on the transcendence of God? Is there a 'heaven' beyond the universe and an 'eternity' beyond cosmic history? (p. 457)

Nürnberger's answer to these questions is not necessarily an emphatic, rather Barthian 'Nein!', although he comes close to that. Instead, his answer is that we do not know. Such agnosticism is explained in terms of his notion of God as the transcendent Source and Destiny of reality. Nürnberger argues that transcendence lies beyond the immanent reality to which we have access so that we cannot speak of God as such: 'we can only speak of human intuitions, notions or concepts of God, which are part of immanent reality. Everything else is speculation or wishful thinking' (2016b:457). ${ }^{20}$

Actually, his main argument is that it is dangerous to place one's hope on such transcendence. There is no need here to reiterate his devastating critique of apocalyptic and other distortions of Christian hope. Instead, Nürnberger insists that Christian hope is best understood as a motivating and empowering vision. It has to be focused on what the reality that we experience ought to become rather than 'the fantasy of a never-never land' (2016b:460). He argues that biblical future expectations emerged and evolved as a series of redemptive responses to historically and situationally conditioned needs and that this produced ever new images of what ought to become (2016b:465, almost verbatim). This does imply a sense of (immanent) transcendence: 'the human imagination must go beyond whatever seems possible at any given point in time' (2016b:472).

Let me state that I am in full agreement with Nürnberger on the social significance of such hope. I endorse the way he explains this as a hoped based on the resurrection of Christ (2016b):

The message of the resurrection of Jesus from the dead ... appealed immediately to the oppressed, enslaved, marginalised, despised, poor, sick and outcast. It appealed also to those whose death was imminent, removing all their fear of what would happen beyond the grave. In this sense, faith in the resurrection is a powerful act of defiance. It wants to emphasise that the world does not have the last word; the regularities that govern

20.Elsewhere I have argued, to the contrary, that the answers that we give to life's big questions (about ultimate origins, ultimate destiny, identity and vocation, what makes the world go round and salvation from evil) do matter even when we realise that these are questions that cannot be answered in any final way. We cannot help but to raise these questions, have to answer them however inadequate our answers may be and the answers that we do give, shape our everyday lives decisively. To raise such questions is not merely speculative but constitutes what it means to be human. That certainly also applies to the question as to what will happen to me when I die To be sure, none of us knows the answer to that intriguing question. To believe that one will leave this earthly vale of tears and will rest in the arms of Jesus will shape on's life as much as to believe that and will rest in the arms of Jesus will shape one's life as much as to believe that one will become food for worms - with far-reaching moral implications, often not for the also 2015). I increasingly share Nürnberger's agnosticism, but not his critique of the speculative nature of such questions. The answers that we do give, inadequate as they may be, matter, in life and in death. 
experienced reality do not have the last word; entropy, death and destruction do not have the last word. God's benevolence has the last word!

This is a protest against experienced reality in the name of a loving God who invites us to join 'him' in 'his' redemptive project. It is a pastoral reassurance in seemingly desperate situations. It is an encouragement to transcend the limitations that constrain our freedom and responsibility; that make us despondent and fatalistic; that deprive us of our joy and our hope; that sap our energy and undermine our resolution to work for a more authentic humanity and make this world a better place. It is the great 'Nevertheless!'. (p. 242)

However, the theodicy question remains. What about the victims of history? What about those who die prematurely, those who know that they will soon die riddled with pain, in impoverished, conflict-ridden conditions, oppressed, guiltridden? Is there no hope in sight for them? Nürnberger's response would be that the alternative, namely to place hope elsewhere, is futile. It would not help to hope for what is impossible, for example, a life that does not presuppose the necessity of death. Indeed, 'To accept the necessity and inevitability of death can be considered a sign of joining the creative, redemptive and sacrificial love of God as it actually manifests itself in the reality we experience' (2016b:509). He adds that for believers it is also irrelevant what happens after their death (2016b):

If you have been with God in this life, sharing God's creative and benevolent intentionality as manifest in Christ, you will be with God in whatever 'future' God may or may not have in store for you. To know that we are reconciled with God for all times and all situations is sufficient for us to go through life and die in peace. (p. 498)

Instead, the focus must be on ensuring optimal well-being in this life, in this dispensation. To that end, hope must be geared to what ought not have become; 'It must respond to the real injustices, atrocities, predicaments and ambiguities experienced in our daily lives, in society and in nature' (2016b:477). As some may put it, the question is not whether there is life 'after' or (better) beyond death, but whether there is life before death. I concur with Nürnberger when he states that to proclaim God's benevolence (2016b):

... fortifies our resolve to withstand failure, frustration, fatalism and despondence ... As such it is exceptionally functional and indispensable for a wholesome human life. As long as the future is open, there is a vision, and where there is a vision there is a mission. (p. 468)

Indeed, 'Christian eschatology is a protest of what ought to become against what has become and seemingly will becomeand that in the name of a powerful and loving God' (2016b:469).

Would it suffice, though, to say 'where there is life there is hope' or even 'where there is hope there is life' if the future is precisely no longer open? What then? What if this hope proves to be in vain, if things become worse or only slightly better? Must we then place our hope in hope, in the power of positive thinking perhaps? If the content of hope cannot be clarified, if we do not know what we hope, only that we hope or, even worse, that to hope is very important, then hoping can still be an act of defiance, but can no longer offer a source of inspiration (see Conradie 2005:15).

Note that the answer cannot be merely to hope for a better future, that things will improve after a victim's death. There is some consolation there but this would be to sacrifice the victims of history for the sake of some uncertain future. The vision of optimal well-being cannot be reduced to a vision for the long-term future but has to confront the here and now, what is around the corner and what can stay true to the emphasis on experiential realism. The long-term future is in any case governed by entropy so that life as we know, indeed the earth and the universe itself will come to an end (a point Nürnberger reiterates throughout the two volumes - e.g. 2016b:460-461).

Nürnberger's eschatology is indeed realistic; it is a nononsense form of hope. Here is what I think constitutes the heart of Nürnberger's eschatology (2016b):

To transcend the given situation is healthy if it is the expression of a defiant protest against evil and inevitability in the name of a benevolent God. It is not healthy if it becomes an expression of a lost hope for this world. While we should train our imagination to go beyond what seems feasible at present, therefore, it should translate into a practical commitment to remove deficiencies in well-being that can be removed.

We cannot overcome death, but we can indeed serve life as long as it lasts. We can indeed try to prevent premature and miserable deaths. We can indeed try to overcome human depravity, social injustice, economic deprivation, physical suffering, frustration and meaninglessness. We can indeed alleviate the consequences of natural catastrophes. We can indeed 'make the world a better place to live in'. We can indeed make our impact on nature ecologically sustainable and economically equitable. But our vision must stay within the limits of time, space and energy that are accessible to us and relevant to our lives as human beings. (p. 479)

In my view its focus on the imminent future implies that it loses something of the comprehensiveness of the vision that it espouses: it does not come to terms with past experiences of pain and injustice except to hope that things will get better in future - because nothing can be done about the past. It does address the long-term future but seems to disallow human wondering about the beyond. ${ }^{21}$

How, then, can one entertain a vision that is not primarily geared towards the future? Even if the focus is on the imminent future, one has to reckon with situations that are not likely to change. Will Stoic protest suffice so that we can become fully human in this life while it lasts (2016b:488)?

21.Admittedly, there are other formulations where Nürnberger leaves the question open ended. I can live (and die!) with the following (2016b):

Because it is authenticity rather than longevity that matters, those who have linked up with God's benevolent intentionality and agency will be able to die in peace, entrusting their lives to the very God from whom they have received it and peace, entrusting their lives to the very God from whom they have received it and
trust that whatever God may do with it will be in line with God's redeeming love. (p. 508) 
Do we really just have to make the best of life by praising God as long as it lasts (2016b:480)? How would one come to terms with the injustices of the past? In the traditional eschatologies that Nürnberger denounces there is room for the consummation of all things, where the focus is not on the final epoch in history but on the whole of history, gathering together every moment of that. Can this be evaded without emptying the content of Christian hope? Does Nürnberger acknowledge the narrative character of the acts of God in such a way that creation, salvation and consummation are held together in suspense or does his emphasis on conceptual clarity override the telling of the story?

\section{A word on the emphasis on God's Word}

I wondered long and hard about the emphasis that Nürnberger puts on God's Word. It appears in the title of all the chapters in Volume I. The Christian faith is essentially understood as a message that is embedded in a living tradition, proclaimed by every successive generation of believers, believed within a community that participates in God's project (2016a:xi).

Nürnberger certainly develops a sophisticated notion of God's Word, if not quite following the Barthian distinction between the Word as Incarnate, Written and Proclaimed (see 2016a:35f). The word is proclaimed, enacted upon, embodied in the church and embedded in the world (2016a:122, 247-261, 277-302). Theologians may be forgiven wondering about the implications of this emphasis as the binary distinctions between Word and Spirit, letter and spirit, word and sacrament (see 2016a:359-365), theory and praxis, orthodoxy and orthopraxy, cognition and emotion, the visible and the audible suggest. If the word is the source of power that seeks to transform reality as it is into what it ought to be, does this not yield a Lutheran caricature of theology as a wordy enterprise. Does this not privilege the ear as more spiritual than the eye, the tongue, the nose or the skin? ${ }^{22}$

Allow me to pursue this argument by drawing on formulations in The Earth in God's Economy: ${ }^{23}$

Theologically, the question is how to understand the relationship between the Word that became flesh and words about the Word that became flesh (the gospel), between word and sacrament, word and salvation, gospel and culture, church and world, theology and sociology. Or, in evolutionary terms, does flesh have to become word (through emergence) before, in theological terms, the Word can become flesh?

For Nürnberger, God is the ultimate Source and Destiny of Reality. This suggests that God as Creator was there long

22. As I have argued elsewhere, there is a need for theological reflection on ail the senses and how they are related to each other (see Conradie 2015, 2016a). Nürnberger's invitation to Systematic Theology offers fertile ground for Nürnberger's invitation to Syste
postgraduate work in this regard.

23.The formulations in the next three paragraphs are a truncated version of my argument (see Conradie 2015:284-285), augmented with references to Nürnberge 2016a, 2016b) before humans emerged (which is the orthodox position). On the basis of the theory of emergence (on which Nürnberger places so much weight), one may wonder whether the notion of 'God' only emerged much later as a result of cultural evolution (the liberal position). Did intentionality play a role from the beginning (before sentient beings emerged) or only subsequent to the emergence of hominids? Or is 'God' another (pantheist, panentheist or process) name for the 'wellspring of novelty' that 'abides in the depths of the universe?'

Or to frame this from another angle: how and where does sin enter into this tension between flesh (the libido) and word (the tongue)? ${ }^{24}$ Is the human will indeed the locus domicilium of sin? The long-standing danger is to associate sin with variability, fragility, the need for food (gluttony), money (desire), friendship (envy) and sexual expression (lust), thus, with nature. But sin can also be linked with idolatry, pride and rebellion against God (thus, the desire to transcend 'nature'). And salvation then? Does salvation enter from the side of the 'flesh' (through genes, medicine, vitamin supplements, muti, technology, economic upliftment, money, bread and wine) or from the side of the 'soul' (through language, culture and ideas - the frightening Word that condemns sin and evil - 2016a:61)? Must the unruly tongue be tamed by an ecstatic experience of speaking in tongues in order to praise God or is it best transformed by the Word (which Nürnberger would prefer, I presume)?

How, then, can the gospel transform the world? Merely through the spreading of new ideas? Through new information and the communication of knowledge that leads to a change of consciousness (2016a:40)? Can ideas really change the world or does change come only through material processes, through bottom-up causation? Or merely through the transforming tactile presence of the Saviour? Is the gospel more than a mere idea, a different perspective, another interpretative framework, a view of the world, the 'eye of faith', seeing the world through God's eyes? Is it only the Word that mediates God's love for us (see 2016a:36)? Yes, God's Word can enter human history and does create its own history (2016:37) but only because that Word became

24.Nürnberger states that 'The Bible maintains that the deepest cause of sin is the desire of the human being to go it alone'. This understands sin mainly as alienation - from oneself, from others and from God. The emphasis on autonomy is perhaps more German than African though. Whether this is really a 'cause' or an explication of the category of sin, is not that clear. See also my discussion in this regard (Conradie 2016b, 2017). Elsewhere Nürnberger offers a remarkably clear answer to this question, worth quoting at length (2016b):

Survival instincts are located in the oldest part of our brains, the so-called 'reptile brain'. A reptile does not have a good or a bad conscience - its brain is simply geared to 'feeding and breeding'. A second layer of the brain, called the 'limbic system', houses our emotions. Emotions are as important for human life as instincts are. But they can also amplify the power of our instincts, overwhelm us and lead us to irrational behaviour.

Both of these faculties are meant to be under the control of the 'pre-frontal cortex', a part of the brain endowed with the faculties of critical assessment, rational argument and conscious decision making. It is hugely more developed in humans than in ther primates. If that is the case, sin is not located in our instincts hum control over us, and the brain functions that put us in control of our lives.

In plain language: what matters is our sense of purpose, our vision of what we and our live worlds are meant to be, our motivation, our commitment, our selfdiscipline, our dedication to a cause that we are meant to serve. It is this faculty that is being renewed and empowered through faith in Christ, present in the Holy that is being renewed and empowered through faith in Christ, present in the Holy
Spirit. Once integrated in a healthy existential process guided by the 'Spirit', Spirit. Once integrated in a healthy existential process guided by the 'Spirit',
instincts and emotions play their God-given and indispensable role. (pp. 438-439) 
flesh - which in evolutionary terms implies 'deep incarnation' (Gregersen). To be sure, for Nürnberger God acts redemptively through our redemptive action (only?) when we share God's intention, God's action and God's vision. This begins with the transformation of our own sinful predisposition into an eagerness to share in Christ's new life in fellowship with God (2016b:392, almost verbatim). But how does such transformation begin? With new information? Through the (enacted) word that prompts action (see 2016b:393)? ${ }^{25}$

For reformed Christians this is a particularly difficult problem given the emphasis on the preaching of the Word so that churches are built as 'mouth-houses' (Luther), with elevated pulpits. Salvation is ex auditu verbi. This is essentially a forensic word of forgiveness. Let us accept that acceptance by God leads to change (2016a:73), that it involves and empowers us (2016a:93f). But could that forgiveness not be expressed even better through embrace (involving the reciprocity of the tactile senses) so that one is aware of being touched (but not necessarily of being observed)? Does the emphasis on the word not imply a thinly veiled preference for the ideal over the material, the spiritual over the bodily? Is the ear more spiritual than the eye because faith is not a matter of seeing but of believing, because God's forgiveness cannot be seen but can only be heard (or felt in the form of an embrace - see Conradie 2016a)? Can we rely only on God's Word to assure us of God's acceptance and to meet our deepest need for acceptance and belonging (2016a:69)? Are words (directed at the ear) 'higher' or more 'significant' than other, more 'natural' signs such as animal tracks (perceived by the human eye) - as has been presumed since Augustine?

How, then, can one do justice to both the verbal (Word) and the bodily (flesh) that is clearly assumed in the symbol of the incarnation? This remains a vexing problem, given the tendency towards a spiritualising and alienating escapism (where knowledge of the world provides an escape from that which is bodily, fragile, subject to change), on the one hand, and scientific reductionism (where words are regarded as a function of genes, brain chemistry, economic conditions, sexual drives, etc.), on the other. The value-richness of higher levels of complexity should be recognised without reducing salvation to that - otherwise ignorance would be regarded as the main underlying problem, while salvation may be equated with (Western) education, cultural refinement, 'civilisation' and (where these are still absent) 'development'. The salvation of the earth has to include the biophysical levels that make the emergence of such 'higher' levels of complexity possible in the first place. Salvation therefore cannot be associated exclusively with the word as if it is the word that has to save the flesh by elevating it to the level of the verbal.

25.For Nürnberger's dialectical understanding of enacted words, see this formulation (2016b):

The Word of God is primarily an enacted Word. ... The Word of God is always both proclaimed and enacted. The Word prompts our attitudes and actions and the interprets them as manifestations of God's attitudes and actions. So the Word of God always has two aspects: it is a redemptive act or event, and it is also an interpretation of that act or event as God's redemptive action. (pp. 393, 394)

A certain priority is thus assigned to the verbal.
How would Klaus Nürnberger respond to this? He can of course speak for himself but let me suggest that this goes right to the heart of his distinction between creative power and benevolent intentionality. He correlates this distinction with the classic theological distinction between two forms of God's revelation, that is, in nature and in scripture (see 2016a:28). God's creative power is expressed in the reality we experience, a reality that is best described by science (not theology). God's benevolent intentionality is proclaimed (through words) on the basis of the biblical witnesses (again 2016a:28). Nürnberger's argument is that we need best practice in both science and faith to regain sanity for the sake of the earth (see 2011). We therefore have to resist the Barthian discrediting of natural theology.

These distinctions are in my view necessary and I support Nürnberger's sentiments here. However, it is the correlation between them that creates some trouble. Once reality as we experience is defined by the sciences and their description of flows of energy (power), the only point of entry for the Christian faith into that reality is through words that can transform that reality - if and only if the emergence of higher level properties are acknowledged as part of that immanent reality. This can by definition happen only late in evolutionary history. Does this position not secularise science, detach the humanities from the natural sciences and isolate the possibility of God's presence in steering evolutionary history?

Indeed, and this may sound odd given Nürnberger's emphasis on history and his arguments against a static notion of perfection (2016b:389), can he do justice to the historical thrust of the Christian story? Is there not a danger that his triad of concepts will begin to function, against his own benevolent intentions, as three eternal abstract truths that play itself out in different ways in different epochs? Indeed God's vision of comprehensive optimal well-being does instil change. It opens up a future that has to be articulated continuously through God's Word. The Word of God therefore has a historical character; it emerges and evolves in history (2016a:121-144). It has a dynamic, indeed a missionary character (2016a:195-244). Likewise, for Nürnberger truth is a dynamic concept; it constantly has to disclose itself as situations change (2016a:429). The vision does move; indeed it is like a 'shifting horizon that moves on as we approach it, revealing ever new vistas, challenges, and opportunities and calling us to tackle any deficiency in well-being in any dimension of life' (2016a:105). He adds that (2016b):

A vision is important to direct us towards an ultimate goal. By its very nature a vision overshoots what seems possible at any point in time. It stretches us; it widens our horizons; it motivates and empowers us to venture beyond reality as it has become, rather than taking it for granted. It helps us to overcome fatalism and despondency and gives us the courage to conquer the future. (p. 375)

However, the vision itself does not seem to change; it remains the same in whatever situation we may find ourselves, namely a vision of comprehensive optimal wellbeing. The vision, it seems, is not something that we can 
see but has to hear about through God's Word. If so, do we not return to a dreaded form of Platonism? What has happened to the Christian story (not the story of Christianity) as an integrated if incomplete story of God's actions of creation, ongoing creation, providence, salvation, the formation and mission of the church, moving towards the consummation of God's work. Indeed, is there any sense of consummation or does entropy have the final word on cosmic history? Is the only hope that we have that we may die in God's forgiving presence (i.e., without comprehensive well-being) or is there room for the consummation of all things?

\section{A last word on the community of scholars}

These reflections on how Nürnberger understands Christian hope would need to suffice. It addresses the question: What hope is there - for or according to Klaus? But what hope is there, then, for Klaus (if not for his eschatology)? Here is his own position in this regard (2016b):

Following the approach of experiential realism, we have to concede that it is not only highly unlikely, but indeed impossible for us to escape our demise. However, hope beyond death may be valid as the defiant protest of faith against the injustice, rejection, futility and meaninglessness we experience in this life and, much more so, when a miserable death seems to deprive us of any kind of redress, dignity, justice, and in fact of any future. This protest may tell us more about our lives while they last than about what may happen beyond our deaths. (p. 484)

If that is the case, this colloquium on Klaus Nürnberger's Invitation to Systematic Theology becomes highly significant. This is one opportunity, neither the first nor I hope the last, to celebrate his life while it lasts. Surely, the symbols of resurrection and eternal life express, at the very least, the reassurance that nothing will separate him from the love of God (2016b:486). It is also an opportunity to celebrate his work and his legacy. May that long outlast him!

\section{Acknowledgements Competing interests}

The author declares that he has no financial or personal relationships that may have inappropriately influenced him in writing this article.

\section{Funding information}

Funding provided through the University of the Western Cape Research Incentive Scheme is acknowledged.

\section{References}

Berkhof, H., 1985, Christelijk Geloof. Een Inleiding tot de Geloofsleer, GF Callenbach, Nijkerk.

Conradie, E.M., 2002, 'Resurrection, finitude, and ecology', in T. Peters, R.J. Russell \& M. Welker (eds.), Resurrection: Theological and scientific assessments, pp. 277-296, WB Eerdmans, Grand Rapids, MI.

Conradie, E.M., 2005, Hope for the Earth - Vistas on a new century, Wipf \& Stock, Eugene, OR.

Conradie, E.M., 2006, Lewe Anderkant die Dood? In Gesprek oor die Hoop op die Opstanding uit die Dood, Lux Verbi.BM, Wellington.

Conradie, E.M. (ed.), 2011a, Creation and salvation, Volume 1: A mosaic of essays on selected classic Christian Theologians, Studies in Religion and the Environment, Vol. 5, LIT Verlag, Berlin.

Conradie, E.M. (ed.), 2011b, Creation and salvation: Dialogue on Abraham Kuyper's legacy for contemporary ecotheology, Brill Publishers, Leiden.

Conradie, E.M. (ed.), 2012a, Creation and salvation, Volume 2: A companion on recent theological movements, Studies in Religion and the Environment, Vol. 6, LIT Verlag, Berlin.

Conradie, E.M., 2012b, 'Between vanity and sanity: Review essay on Klaus Nürnberger's regaining sanity for the earth (2011)', Journal of Theology for Southern Africa 144, 126-143.

Conradie, E.M., 2013a, 'Only a fully Trinitarian Theology will do, but where can that be found?', Ned Geref Teologiese Tydskrif 54(1\&2), 1-9. https://doi.org/10.5952/ 54-1-2-318

Conradie, E.M., 2013b, Saving the Earth? The Legacy of Reformed Views on "Re-creation", Studies in Religion and the Environment Vol. 8, LIT Verlag, Berlin.

Conradie, E.M., 2014, 'What on earth did God create? Overtures to an ecumenical theology of creation', The Ecumenical Review 66(4), 433-453. https://doi.org/ 10.1111/erev.12120

Conradie, E.M., 2015, The earth in god's economy: Creation, salvation and consummation in ecological perspective, Studies in Religion and the Environment, Vol. 10, LIT Verlag, Berlin.

Conradie, E.M., 2016a, 'Is the ear more spiritual than the eye? Theological reflection on the human senses', in D. Evers, M. Fuller, A. Runehov \& K.-W. Saether (eds.), Issues in science and theology: Do emotions shape the world?, pp. 177-188, Springer, Heidelberg.

Conradie, E.M., 2016b, 'Penultimate perspectives on the root causes of environmental destruction in Africa', Scriptura 115, 1-19. https://doi.org/10.7833/115-0-1279

Conradie, E.M., 2017, Redeeming sin? Social diagnostics amid ecological destruction, Lexington Books, Lanham.

Nürnberger, K., 1995, Making ends meet: Personal money management in a Christian perspective, Cluster, Pietermaritzburg.

Nürnberger, K., 1998, Beyond Marx and market: Outcomes of a century of economic experimentation, ZED Books, London.

Nürnberger, K., 1999, Prosperity, poverty \& pollution. Managing the approaching crisis, Cluster, Pietermaritzburg.

Nürnberger, K., 2002, Theology of biblical witness. An evolutionary approach, LIT Verlag, Hamburg.

Nürnberger, K., 2011, Regaining sanity for the earth, Cluster, Pietermaritzburg.

Nürnberger, K., 2016a, Faith in Christ today: Invitation to systematic theology, Volume I: Life in the presence of God, Cluster, Pietermaritzburg.

Nürnberger, K., 2016b, Faith in Christ today: Invitation to systematic theology, volume II: Involved in God's project, Cluster, Pietermaritzburg.

Van Ruler, A.A., 1989, Calvinist trinitarianism and theocentric politics: Essays towards a public theology, J. Bolt (ed.), Edwin Mellen Press, Lampeter.

Ward, G., 2016, How the light gets in: Ethical life I, Oxford University Press, Oxford. 